\title{
IDENTIFIKASI BENTUK EROSI TANAH MELALUI INTERPRETASI CITRA GOOGLE EARTH DI WILAYAH SUMBER BRANTAS KOTA BATU
}

\author{
Rudi Hartono ${ }^{1}$ \\ E-mail: rudi.hartono.fis@um.ac.id
}

\begin{abstract}
Abstrak: Erosi tanah adalah penyumbang terbesar dari terjadinya degradasi lahan. Citra penginderaan jauh google earth merupakan salah satu alat yang digunakan untuk mempermudah kegiatan manusia dalam penelitian erosi tanah. Kriteria kawasan rawan bencana alam adalah kawasan yang diidentifikasi sering dan berpotensi tinggi mengalami bencana alam seperti banjir, letusan gunung berapi, gempa bumi, dan tanah longsor/erosi. Berdasarkan hasil kajian dari peta kontur, ketinggian, geologi dan jenis tanah serta vegetasi yang ada di wilayah berlereng (kemiringan diatas 50\%) untuk kawasan rawan bencana di Kota Batu yang perlu dikendalikan secara ketat adalah laju erosi tanah yang mengancam terutama lahan pertanian. Beberapa tahun yang lalu kondisi lahan di Junggo Bumiaji Batu masih berfungsi sebagaimana mestinya tidak ada ahli fungsi lahan seperti sekarang. Tetapi, karena pertambahan masyarakat di Sumberbrantas mengakibatkan sebagian dari hutan dimanfaatkan oleh penduduk di sekitar sebagai lahan pertanian untuk memenuhi kebutuhan hidupnya. Interpretasi citra satelit merupakan salah satu teknologi yang digunakan dalam kajian geografi. Citra satelit yang ada di google earth merupakan mosaic citra dari hasil penginderaan jauh yang diperoleh menggunakan satelit yang mengorbitkan ke angkasa luar, untuk aplikasi dalam bidang cuaca, pertanian, kehutanan, pemetaan sumberdaya alam, kajian bencana alam, lingkungan dan kelautan. Dari penggunaan citra google earth ini dapat diinterpretasi bentuk erosi lembar, erosi alur dan erosi parit.
\end{abstract}

Keywords: identifikasi, bentuk erosi tanah, citra goole earth

\section{PENDAHULUAN}

Erosi tanah adalah penyumbang terbesar dari terjadinya degradasi lahan. Walaupun degradasi lahan bukan merupakan peristiwa ekonomi akan terapi proses ini berkaitan erat dengan penurunan mutu la-han yang menyebabkan menurunnya pro-duksi pertanian dan meningkatnya biaya pencegahan degradasi lahan yang meru-pakan problem ekonomi.

\footnotetext{
${ }^{1}$ Dosen Jurusan Geografi UM
}

Dampak langsung dari erosi tanah yang utama adalah penurunan produktivitas tanaman yang diakibatkan oleh kemerosotan produktivitas tanah, kehilangan unsur hara tanah dan kehilangan lapisan tanah yang baik/subur bagi berjangkarnya akar tanaman, sedangkan dampak tidak langyung adalah pelumpuran dan pendangkalan waduk, kerusakan ekosistem 
perairan, memburuknya kualitas air, me-ningkatnya frekuensi dan masa kekerin-gan, serta tertimbunnya lahanlahan per-tanian.

Menurut Utomo (2000) besar tingkat erosi di Indonesia mencapai $173 \mathrm{Ha} / \mathrm{Th}$. Berdasarkan besarnya tingat erosi tersebut maka perlu adanya suatu upaya guna pengendalian tingkat erosi. Dalam hal ini salah satu upaya dalam pengendalian yakni pemetaan daerah-daerah yang berpotensi erosi. Peta merupakan salah satu alat yang digunakan untuk mempermudah kegiatan manusia dalam pencarian suatu daerah. Seiring berkembangnya zaman, maka semakin jelaslah keberadaan peta sangatlah penting. Semakin pentingnya keberadaan peta menyebabkan banyak pakar geografi melakukan riset untuk menemukan inovasi-inovasi dalam perkembangan peta. sehingga digunakan suatu citra satelit yang akan menghasilkan peta pada akhirnya.

Seberapa besar peran citra google earth dapat digunakan untuk menidentifi-kasi bentuk erosi tanah, masih belum ba-nyak diungkap dalam suatu laporan pene-litian.

Kriteria kawasan rawan bencana alam adalah kawasan yang diidentifikasi sering dan berpotensi tinggi mengalami bencana alam seperti banjir, letusan gunung berapi, gempa bumi, dan tanah longsor/erosi. Berdasarkan hasil kajian dari peta kontur, ketinggian, geologi dan jenis tanah serta vegetasi yang ada di wilayah berlereng (kemiringan diatas 50\%) untuk kawasan rawan bencana di Kota Batu yang perlu dikendalikan secara ketat karena pengembangan kawasan budidaya terutama pada kegiatan pertanian bukan pada tanaman keras dan kegiatan permu-kiman.

Dampak yang dominan dari kawasan rawan bencana yang ada di Kota Batu adalah erosi dan tanah longsor. Erosi dan tanah longsor juga terjadi di desa Sumber Brantas, dimana tanah longsor ini disebabkan oleh kerusakan hutan. Kerusakan hutan ini disebabkan oleh aktifitas alih fungsi lahan dari hutan menjadi areal pertanian oleh penduduk setempat sehingga menyebabkan turunnya potensi dari fungsi hutan yang sesungguhnya di wilayah ini. Masyarakat setempat memanfaatkan hutan untuk memenuhi kebutuhan hidup setiap harinya. Dahulu sebelum tahun 2000 hutan di Junggo masih berfungsi sebagaimana mestinya tidak ada ahli fungsi lahan seperti sekarang. Tetapi, karena pertambahan masyarakat di Sumberbrantas mengakibatkan sebagian dari hutan dimanfaatkan oleh penduduk di sekitar sebagai lahan pertanian untuk memenuhi kebutuhan hidupnya. Dari tahun ke tahun hutan semakin hilang karena ahli fungsi lahan. Lahan yang dulunya hutan kini sudah berubah menjadi lahan pertanian.

Seiring dengan keberagaman sumber daya alam di wilayah Kota Batu, prosesproses geomorfologi di setiap desanya juga sangat beragam. Dari keberagaman inilah tentunya banyak hal yang sangat perlu dikaji khususnya dalam ilmu kegeografian. Salah satu proses geomorfologi yang menjadi fenomena dan sering terjadi yaitu erosi. Erosi merupakan salah satu proses geomorfologi yang sering terjadi di Batu. Proses ini disebabkan oleh berbagai faktor. Erosi merupakan peristiwa yang sering berdampak negatif bagi masyarakat. Seperti halnya erosi tanah akan berpengaruh negatif terhadap produktivitas lahan 
Rudi Hartono. Identifikasi Bentuk Erosi Tanah Melalui Interpretasi Citra Google

Earth Di Wilayah Sumber Brantas Kota Batu

yang meliputi kurangnya ketersediaan

air, nutrisi, bahan organik, dan menghambat kedalaman perakaran.

Citra satelit merupakan salah satu perkembangan dari teknologi pemetaan yang kian merambah dalam ilmu geografi. Citra satelit yang ada di google earth merupakan gambar dari hasil penginderaan jauh yang diperoleh menggunakan satelit yang mengorbitkan ke angkasa luar. Banyak satelit yang digunakan untuk mengamati objek-objek di permukaan bumi yang disesuaikan dengan informasi tutupan lahan yang dibutuhkan untuk berbagai bidang aplikasi, seperti aplikasi bidang pertanian, kehutanan, dan kelautan. Salah satu citra diantaranya yaitu citra satelit Landsat. Berkaitan dengan masalah di atas, maka tujuan penelitian ini adalah: 1). Mengidentifikasi bentuk-bentuk erosi tanah di wilayah penelitian melalui intrepretasi citra google earth di wilayah penelitian,

2). Mengetahui unsur-unsur interpretasi citra yang berperan dalam dalam pengidentifikasian bentuk-bentuk erosi di wilayah penelitian.

\section{METODE}

Rancangan Penelitian

Penelitian ini dirancang secara survei dengan didahului studi terhadap peta rupabumi Indonesia, peta tanah, dan peta penggunaan lahan, serta interpretasi citra landsat-Google Earth terhadap kenam-pakan bentuk-bentuk erosi di daerah pe-nelitian.

Daerah penelitian secara administratif terletak di Dusun Sumberbrantas
Kecamatan Tulungrejo Kecamatan Buni-aji Wilayah Kota Batu.

Metode yang digunakan ialah interpreasi citra Google Earth dan diikuti dengan pengukuran lapangan terhadap bentuk-bentuk erosi, kemiringan lereng, penggunaan lahan, dan uji manipulasi tekstur tanah. Sebagai satuan pemetaan, digunakan unit lahan yang tampak pada citra Google Earth. Hasil dari penelitian ini berupa: laporan kemampuan peranan interpretasi citra Google Earth dalam identifikasi bentuk-bentuk erosi tanah (khususnya unsur interpretasi citra mana yang paling dominan), peta tingkat erosi tanah secara kualitatif, dan artikel yang akan dimuat dalam jurnal terakreditasi.

Sasaran Penelitian, Alat dan Bahan

Sasaran penelitian ini adalah lahan di dusun Sumber Brantas Desa Tulungrejo Kecamatan Buniaji Kota Batu. Unsur-unsur pembentuk satuan lahan yang me-rupakan parameter kejadian erosi akan di-interpretasi dari citra dan diuji di lapa-ngan.

Dalam penelitian ini alat dan bahan yang akan digunakan antara lain: 1). Komputer dengan software ArcView untuk interpretasi citra 2). Global Positioning System untuk mengetahui posisi lahan yang diuji lapangan, 3) Peta ukur 50 meter untuk mengukur jarak dan ke-dalam bentuk-bentuk erosi, 4) Lembar observasi/pengukuran lapangan 5) Peta RBI Indonesia lembar Batu, Pujon, Bumiaji dengan skala 1: 25.000 tahun 2001, 6) Peta Kemiringan Lereng skala 1:50.000 tahun 2009, 7) Peta Penggu-naan Lahan Wilayah Kota Batu skala 1:50.000 tahun 2010, 8). Citra Google Earth tahun 2014 unfix scale. 
Analisis Data

Analisis data dalam penelitian ini di-lakukan dengan interpretasi terhadap citra Google Earth, peta administrasi peta penggunaan lahan, dan peta jenis tanah, serta analisis tekstur tanah.

Interpretasi citra Google Earth: Interpretasi citra akan dilakukan secara $O n$ Screen Interpretation, yaitu pengamatan dan identifikasi bentuk-bentuk erosi langsung pada layar 33actor33e. Interpretasi ini menggunakan 33actor-unsur interpretasi citra, yaitu: warna, teksur objek, bentuk, ukuran, situs, asosiasi, dan pola. Dengan demikian bentuk-bentuk erosi (alur, parit, gully) akan diinterpretasi secara monoskopik, artinya tidak dilakukan secara tiga demensi.
Sebelum melakukan interpretasi ben-tuk-bentuk erosi, terlebih dahulu dilaku-kan interpretasi unit lahan yang akan menjadi unit pemetaan bentukbentuk erosinya. Adapun faktor interpretasi ben-tuk bentuk erosi ialah sebagai berikut: 1) rona/warna, 2) tekstur, 3) pola, 4) uku-ran/tinggi, 5) bentuk, 6) asosiasi, dan 7) situs

\section{HASIL PENELITIAN}

Sekilas Kondisi Geografi Wilayah Batu

Kota Batu secara astronomis terletak antara $112^{\circ} 17^{\prime} 10,90$ ' sampai dengan $112^{\circ} 57^{\prime}$ Bujur Timur dan $7,44^{0} 55^{\prime} 00^{0}$ sampai dengan $8^{\mathrm{O}} 26^{\prime} 35,45^{\prime}$ ' Lintang Se-latan.

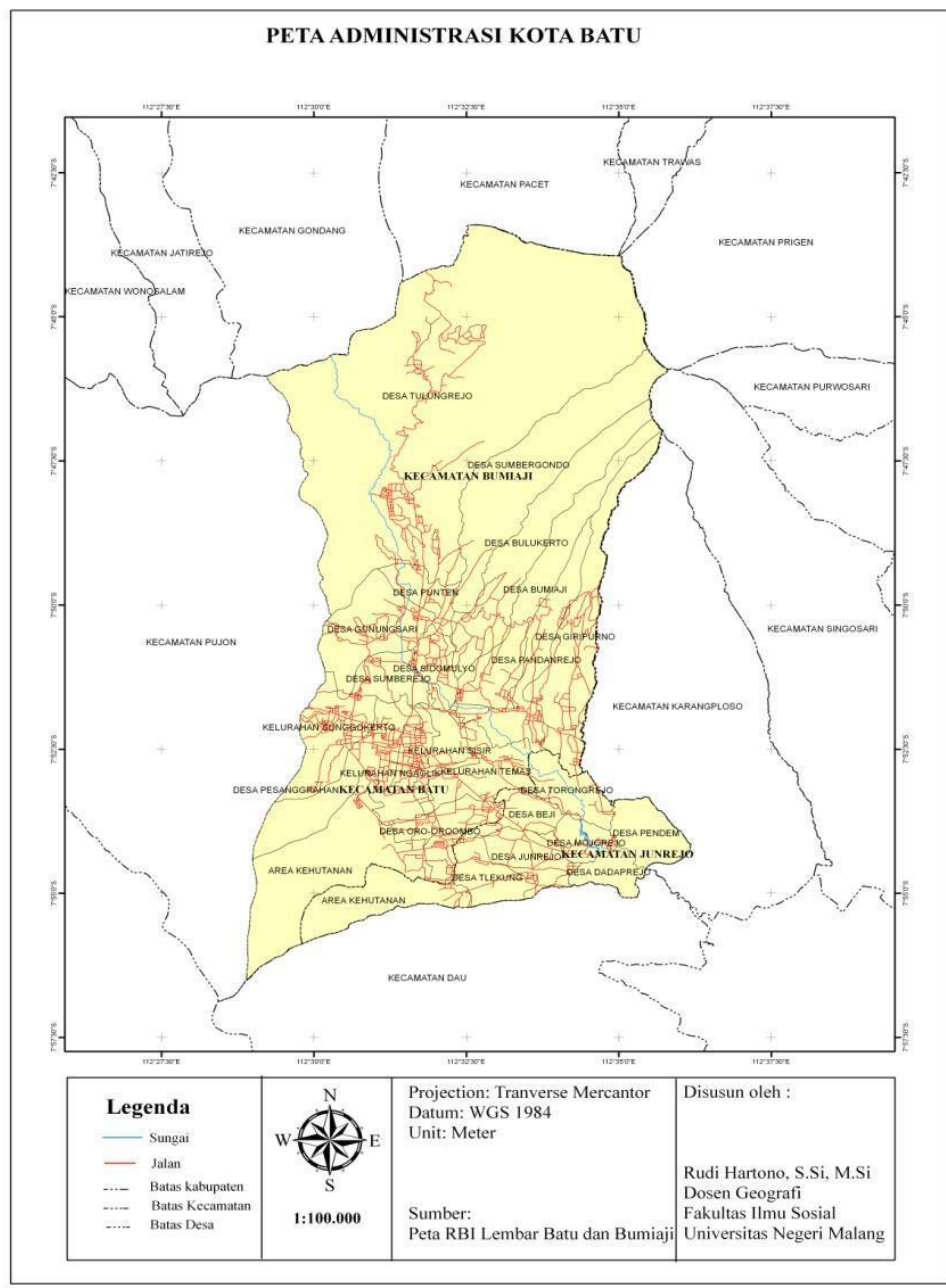

Gambar 1. Peta Wilayah Kota Batu 
Luas kawasan Kota Batu secara keseluruhan adalah 19908,750 Ha atau $199 \mathrm{~km}^{2}$, terdiri dari 3 Kecamatan yaitu: Ke-camatan Batu dengan luas 4545,81 Ha; Kecamatan Junrejo dengan luas 2565,02 Ha; dan Kecamatan Bumiaji dengan luas 12797,92 Ha. Jumlah Kelurahan dan De-sa terdapat 23, dengan jumlah RW 220, dan RT 1017.

Wilayah Kota Batu secara geologis tersusun atas endapan gunung api yang aktif pada masa lampau. Secara berurutan (dimulai yang tertua), tata urutan stratigrafi tersusun atas: 1) Batuan Gunung Api Anjosmoro Tua, tersusun atas breksi gunung api, tufbreksi, tuf dan lava. Batuan Gunung Api Anjosmoro diduga sebagi alas dan berumur plistosen awaltengah. Beberapa tempat tertindih tak selaras oleh batuan gunung api ArjunoWelirang. Desa yang termasuk Batuan Api Gunung Anjosmoro tua ini adalah sebagian kecil di daerah utara desa Tulungrejo kecamatan Bumiaji, 2) Batuan Gunung Api Kwarter Bawah, Batuan ini terbentuk hasil aktifitas Gunung Api Anjosmoro muda dan terdir atas breksi gunung api, tuf breksi, lava dan aglomerat. Batuan gunung api ini diduga berumur plistosen tengah dan tertindih oleh batuan gunung api kwarter tengah. Daerah yang termasuk ke dalam daerah batuan gunung api kwarter bawah ini meliputi: desa Punten kecamatan Bumiaji, desa Gunungsari kecamatan Bumiaji, desa Sumberejo kecamatan Batu. 3) Batuan Gunung Api Kwarter Tengah, terbentuk dari aktifitas Gunung Api Kawi-Butak dan aktifitas Gunung Api Ringgit yang terjadi di masa kwarter tengah. Batuan ini tersusun atas

\footnotetext{
${ }^{1}$ Dosen Jurusan Geografi UM
}

breksi gunung api, tuf, lava, aglomerat dan lahar. Batuan gunung api diduga berumur plistosen akhir dan tertindih oleh batuan gunung yang lebih muda. Daerah yang termasuk ke dalam daerah batuan gunung api kwarter bawah ini adalah bagian selatan desa Tlekung kecamatan Junrejo, 4) Batuan Gunung Api Arjuno/ Welirang, terbentuk karena aktifitas Gunung Arjuno dan Gunung Welirang yang terjadi di masa kuarter dan tersusun oleh breksi gunung api, lava, breksi tufan dan tuf. Daerah yang termasuk kedalam daerah Batuan Gunung Api Arjuna-Welirang ini adalah meliputi sebagian besar desa Tulungrejo, desa Sumbergondo, desa Bumiaji, desa Giripurno, desa Pandanrejo, desa Sidomulyo, desa Bulukerto, 5) Batuan Gunung Api Kwarter Atas, terutama dibentuk oleh aktifitas Gunung Panderman pada masa kuarter atas dan tersusun oleh breksi gunung api, lava, tuf, breksi tufan, aglomerat dan lahar. Daerah yang termasuk daerah batuan gu-nung api kuarter atas atau Panderman ini adalah, meliputi : kelurahan Ngaglik, ke-lurahan Sisir, kelurahan Temas, desa Beji, desa Torongrejo, desa Mojorejo, desa Dadaprejo, desa Pendem, desa Oro-oro Ombo, sebagian utara desa Tlekung, kelurahan Songgokerto, desa Pesanggrahan, desa Junrejo.

Secara umum wilayah Kota Batu merupakan daerah perbukitan dan pegunungan. Ada tiga gunung yang telah diakui secara nasional, yaitu Gunung Panderman (2.010 $\mathrm{m}$ dpl), Gunung Welirang (3.156 m dpl), dan Gunung Arjuno (3.339 m dpl). 


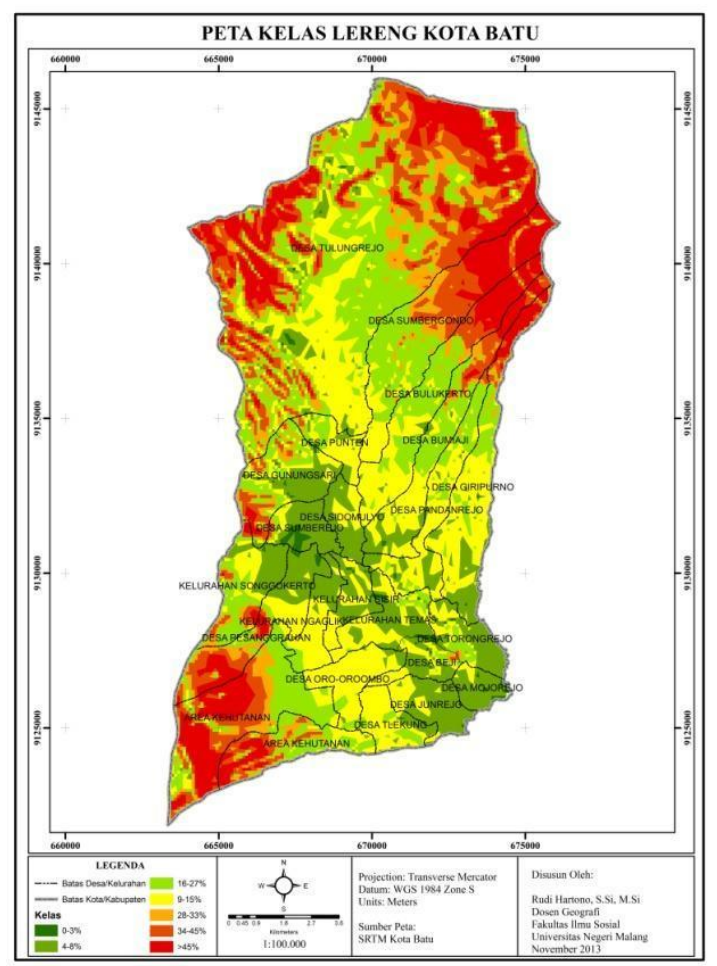

Gambar 2. Peta Kelas Lereng Kota Batu

Adapun jenis tanah yang ada di Kecamatan Bumiaji terdiri dari: 1) Alfisol, adalah tanah yang relatif muda banyak mengandung beberapa mineral yaitu mineral primer yang mudah lapuk, mineral kristalin dan kaya unsur hara. Proses pembentukan alfisol memerlukan waktu yang lama hingga 5000 tahun karena lambatnya proses akumulasi tanah liat. 2) Andosol, adalah tanah yang berkem-bang dari bahan vulkanik seperti abu vul-kan, batu apung, sinter, lava serta dido-minasi oleh mineral short range order (alophan, imogolit, ferihidrit) atau kom-pleks Alhumus. Jenis tanah ini memiliki lapisanlapisan andik yang tebal seluruh- nya sedikitnya $35 \mathrm{~cm}$ pada kedalaman 60 $\mathrm{cm}$ teratas. Jenis tanah andosol umumnya adalah tanah yang subur dan tidak menimbulkan erosi. Kandungan bahan organik yang tinggi dan cenderung kompleks membuat tanah ini terhindar dari limpasan permukaan, penurunan infiltrasi, dan pengurangan agregat tanah yang menyebabkan erosi. Tanah ini dapat menimbulkan erosi apabila dalam pengelolaanya salah, sehingga kandungan bahan organik yang ada menjadi berkurang dan perlindungan tanah terhadap butiran-butiran air hujan juga ikut mengalami penurunan. Jenis tanah ini misalnya dijumpai di Desa Giripurno. 3) Entisol, merupakan tanah 
Rudi Hartono. Identifikasi Bentuk Erosi Tanah Melalui Interpretasi Citra Google

Earth Di Wilayah Sumber Brantas Kota Batu

yang baru berkembang yang berasal tidak hanya dari bahan induk saja tetapi sudah proses pembentukan tanah yang menghasilkan epipedon okhrik. Hal ini terjadi akibat pembentukan struktur dan pencampuran bahan organik dengan bahan mineral di lapisan atas. Entisol dapat terbentuk karena dipengaruhi oleh beberapa faktor yaitu iklim yang sangat kering, erosi yang kuat, pengendapan terus-menerus, imobilisasi tanah, bahan induk yang sulit mengalami pelapukan atau tidak permeabel, bahan induk yang tidak subur, selalu terdapat genangan air, waktu yang sangat singkat belum memungkinkan perkembangan tanah, dan perubahan yang drastis dari vegetasi. Janis tanah ini terdapat pada kedalaman kurang dari $50 \mathrm{~cm}$. Jenis tanah ini digunakan sebagai usaha pertanian. Entisol dijumapai di teras-teras sungai di desa Sidomulyo. 4) Inceptisol, adalah tanah yang belum matang (immature) dengan perkembangan profil yang lebih lemah dibanding dengan dengan tanah matang dan masih banyak menyerupai sifat bahan induknya. Beberapa faktor yang memengaruhi pembentukan inceptisol yaitu bahan induk yang sangat resisten, terdapat dalam posisi yang curam atau lembah dengan kemiringan lereng, permukaan geomorfologi yang muda sehingga pembentukan tanah belum lanjut. Jenis tanah ini terdapat pada kedalaman 20-50 cm di bawah permukaan tanah. Kegunaan dari inceptisol adalah untuk pertanian.

Jenis tanah ini merupakan tanah yang berada pada kemiringan lereng yang curam atau lembah, hal ini memenyebabkan tanah inceptisol memiliki potensi terhadap erosi. Lereng yang curam me- mengaruhi erosi karena, kecepatan air saat terjadi limpasan umumnya ditentukan oleh kemiringan lereng yang tidak terputus dan panjang serta terkonsentrasi pada saluran-saluran sempit yang mempunyai potensi besar untuk terjadinya erosi alur dan parit (Asdak, 2007: 353). 5) Mollisol adalah tanah yang mempunyai epipedon molik dan kejenuhan basa (pH 7) dan seluruh bagian solum tanah lebih dari 50\%. Proses pembentukan mollisol yaitu penyebaran akar-akar ke dalam profil tanah, pelapukan bahan organik yang membentuk senyawa-senyawa stabil dan gelap, pencampuran bahan organik dan bahan mineral, eluviasi dan iluviasi organik serta beberapa koloid mineral melalui rongga-rongga tanah sehingga terdapat selaput bahan organik, dan pembentukan senyawa ligno protein yang resisten sehingga warna tanah menjadi hitam. Jenis tanah ini terdapat pada kedalaman $18 \mathrm{~cm}$ yang merupakan persyaratan dari epipedon molik. Jenis tanah ini dapat digunakan sebagai lahan pertanian. Molisol merupakan jenis tanah yang tahan terhadap erosi, kerena dalam pembentukannya terdapat penyebaran akar-akar ke profil tanah. Akar-akar tersebut sangat membantu tanah dalam proses infiltrasi. Proses infiltrasi yang berjalan dengan baik maka menutup kemungkinan terjadi limpasan permukaan saat terjadi hujan. Jenis tanah ini selain tahan terhadap erosi juga sangat subur, sehingga pertumbuhan tanaman dapat berkembang dengan baik. Tanaman yang tumbuh dapat melindungi tanah dari pukulan butiran air hujan yang menimbulkan erosi percikan. 
Keterbatasan Citra Google-Earth untuk identifikasi bentuk Erosi Tanah

Seperti telah disebutkan di depan bahwa citra landsat ETM mempunyai resolusi spasial 15 meter, itu artinya objek yang bisa direkam oleh sensor Landsat ETM di Bumi minimal harus berukuran 15 meter agar bisa tampak sebagai objek individu, kecuali bentukan yang memanjang seperti jalan dan sungai. Citra Google-Earth merupakan mosaic citra landat ETM dengan "single Band", sehingga tidak bisa untuk dilakukan analisis "spectral band" dari citra itu. Namun demikian karena citra Goole-Earth sudah didesain sebagai "digital Globe" maka interpretasi akan bisa lebih mudah dengan menggunakan fasilitas zoom-out maupun zoom-in. Jikalau interpretasi hanya ditujukan pada faktor ukuran objek saja, maka identifikasi bentuk erosi akan tidak bisa maksimal dilakukan. Oleh karena itu, interpretasi dilakukan dengan mempertimbangkan: rona objek, situs, pola dan penggunaan lahan yang ada.

Perlu diketahui bahwa citra GoogleEarth yang dicetak pada laporan ini skalanya lebih kecil dibandingkan dengan skala pada saat interpretasi. Hal ini dilakukan karena keterbatasan ukuran kertas.
Bentuk Erosi Tanah di Desa Tulungrejo Bumiaji Batu

Faktor yang berpengaruh terhadap erosi tanah di Desa Tulungrejo Batu yang diduga berperan adalah curah hujan, kemiringan lereng, dan penggunaan lahan, Faktor curah hujan tidak bisa diubah sedangkan faktor kemiringan lereng dapat diatasi dengan teknik konservasi yaitu pembuatan teras dan juga teknik vegetatif. Faktor penggunaan lahan berperan dalam tindakan konservasi yang dilakukan di Tulungrejo. Sebagai contoh, untuk lahan tanaman ketang maka petani membuat kontur searah lereng dengan tujuan drainase pada lahan itu bagus sehingga tanaman kentang tidak busuk. Oleh karena itu, penggunaan lahan menentukan praktek konservasi yang ada pada lahan itu.

Seperti telah dituliskan pada batasan penelitian, lokasi penelitian berada di dusun Sumberbrantas desa Tulungrejo Kecamatan Bumiaji Kota Batu yang luasnya lebih kurang 18 km2. Dari Data Penelitian ini menggunakan citra Google Earth yang dibesarkan (zoom-out) semaksimal mungkin sampai kemampuan pixelnya maksimum. 


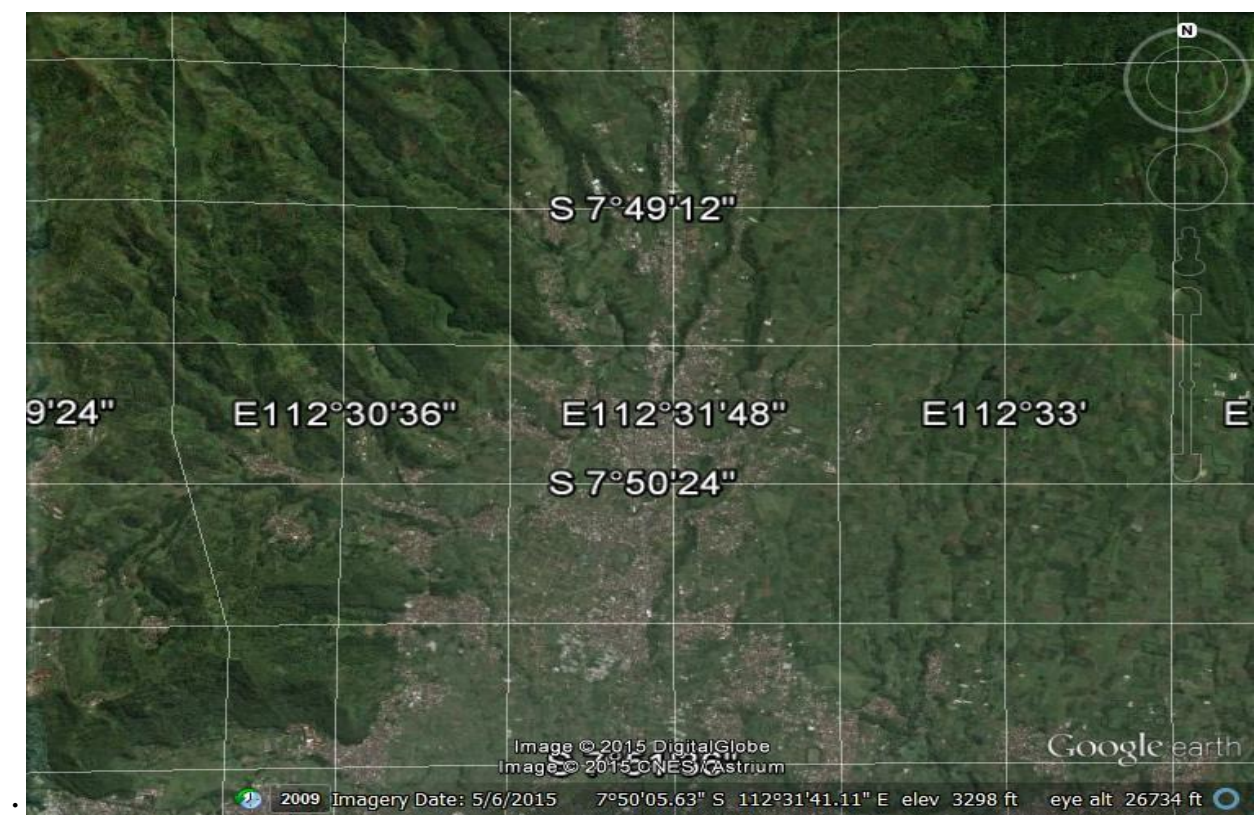

Gambar 3. Citra I - Liputan citra Google-Earth daerah Tulungrejo Bumiaji Batu

Adapun bentuk erosi permukan yang dapat diinterpretasi adalah sebagai berikut: 1) Kenampakan erosi parit (Gully Erosion), erosi parit adalah bentuk-bentuk erosi tanah yang mempunyai kedalaman maksimum 0,5 meter. Kedalaman 0,5 meter ini akan terdeteksi bayangannya pada citra google earth skala 1:20.000. Erosi parit dideteksi keberadaannya dari bayangan tebing paritnya yaitu kenampakan dengan rona gelap memanjang (Lihat pada gambar 4.3. pojok kiri bawah). 2) Kenampakan erosi alur (Rill erosion), erosi alur adalah alur-alur erosi yang terbentuk oleh aliran alir. Alur ini akan hilang apabila tanah dibajak untuk penyiapan lahan. Pada citra Google Earth dengan skala 1:1.000 pola alur masih bisa terdeteksi (Lihat Citra 2 pada Titik No 2). Jarak 0,5 meter akan tergambar pada citra itu sejauh 0,5 milimeter. Jikalau itu jarak vertikal (kedalaman alur) akan sangat sulit terdeteksi. Dengan demikian, pola garisgaris yang terdeteksi pada citra itu adalah bentuk-bentuk erosi alur. 3) Kenampakan erosi permukaan/erosi lembar (Sheet erosion), erosi lembar hanya terjadi pada bagian atas tanah. Tanda-tanda di lapangan apabila telah terjadi erosi lembar adalah dijumpainya kerikil/batu yang ditopang oleh tanah, itu menunjukan bahwa tanah yang tidak terlindungi oleh batu/kerikil sudah hilang tererosi.

Erosi ini dikenal pada citra Google Earth dari perubahan rona tanah pada lahan terbuka Rona pada tanah yang mengalami erosi lembar terlihat lebih cerah dibandingkan rona tanah di sekitarnya yang tidak terkena erosi lembar. 


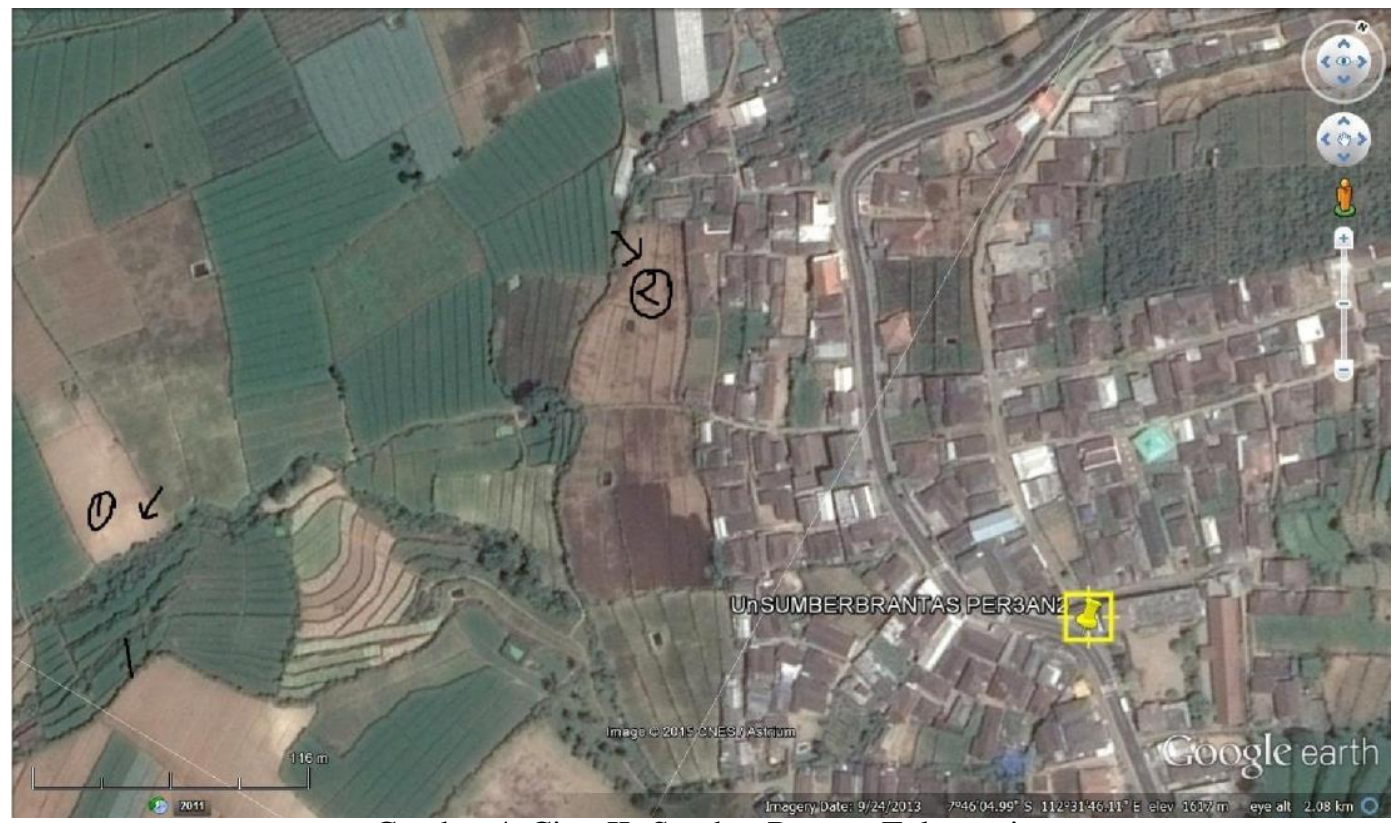

Gambar 4. Citra II- Sumber Brantas Tulungrejo

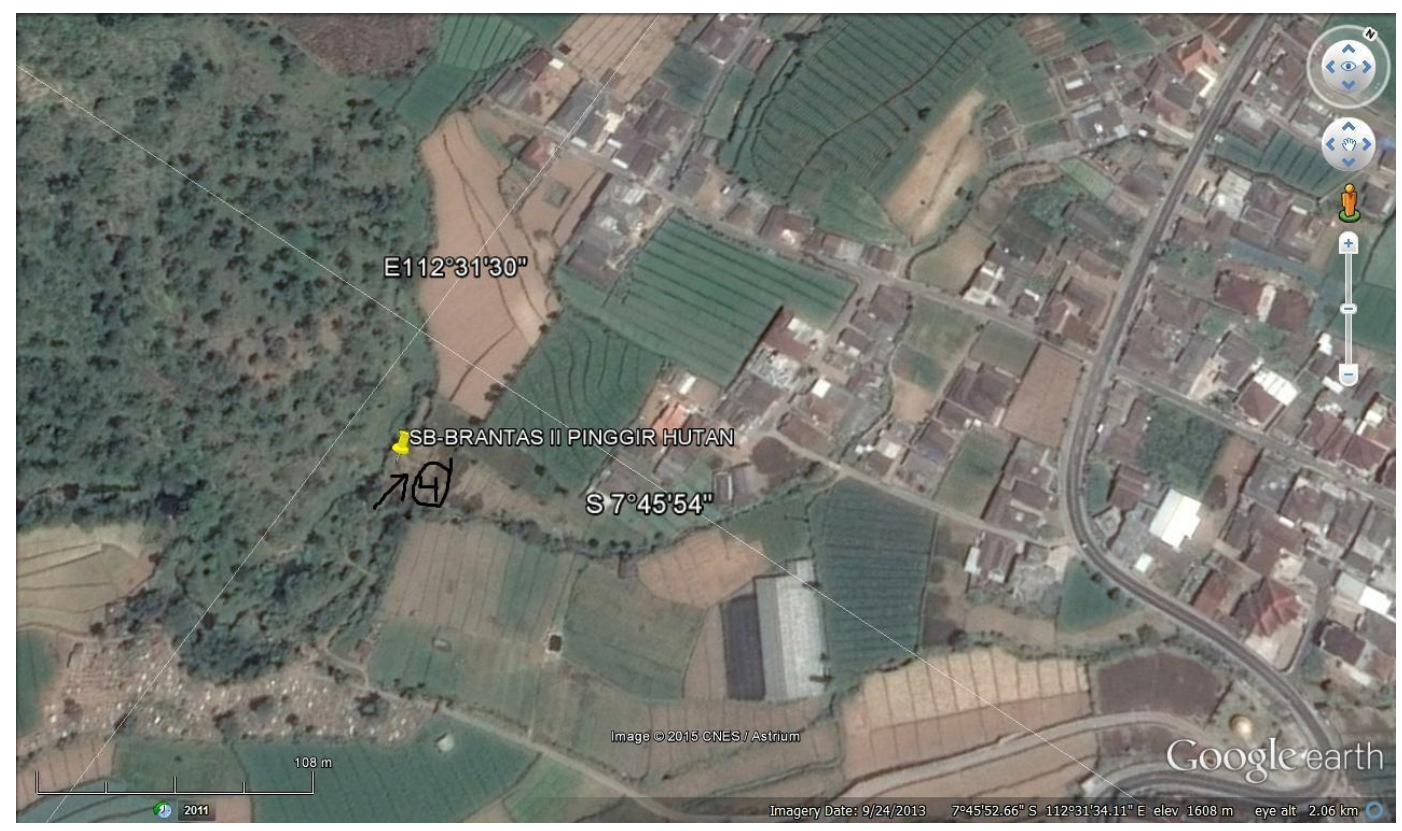

Gambar 5. Citra III- Sumberbrantas

\section{PEMBAHASAN}

Secara teoritis citra landsat Thematic Mapper (TM) yang dibuat mosaik seperti pada Google Earth dapat digunakan untuk pemetaan tanah, khususnya pada saluran biru (1) dengan panjang gelombang 
Rudi Hartono. Identifikasi Bentuk Erosi Tanah Melalui Interpretasi Citra Google

Earth Di Wilayah Sumber Brantas Kota Batu

$(0,45-0,52) \mu \mathrm{m}$. Saluran biru mampu menembus perairan bahkan sedimen/ kekerhan air bisa terdeteksi, serta membedakan kondisi tanah bila tanah itu terbuka.

Lahan yang tergambar pada citra II berada pada relief lokal agak datar dengan kemiringan lereng (4-8) \% (Lihat peta lereng pada gambar 4) dengan kata lain tidak akan ada erosi parit yang terjadi karena lahan dengan kemiringan seperti itu air hujan akan lebih lambat lajunya dan tidak akan meyatu membentuk alur aliran yang lebih besar. Petani pada lahan itu membuat teras guna penamanan sayuran sawi. Pembuatan teras ini mengurangi laju kecepatan aliran air.

Untuk erosi lembar (sheet erosion) tampak dengan rona coklat cerah. Tingkat kecerahan diakibatkan oleh tipisnya tanah permukaan sehingga yang memantulkan energy/sinar matahari adalah tanah yang belum matang/regolith. Erosi lembar ini terjadi pada situs di lahan pertanian terbuka, tidak ada tumbuhan pelindung ataupun penahan angin. Lahan secara keseluruhan digunakan untuk sayuran.

Pola yang terlihat pada citra I tidak jelas, artinya tidak ada pola yang muncul dari tanah yang telah terkena erosi lem-bar. Sedikit agak ke selatan dari titik erosi lembar ini juga dijumpai erosi yang sama. Ini terlihat dari ronanya yang coklat ce-rah.

Untuk erosi alur (rill erosion) tampak dengan rona coklat agak gelap. Rona coklat agak gelap diakibatkan oleh alur-alur tanah permukaan tanah yang menghasilkan bayangan, sehingga pantulkan ener- gy/sinar matahari tidak begitu banyak. Erosi alur ini terjadi pada situs di lahan pertanian terbuka, tidak ada tumbuhan pelindung ataupun penahan angin. Lahan secara keseluruhan digunakan untuk sayuran. Pola yang terlihat pada citra II menyebar, artinya pola yang muncul dari tanah yang telah terkena erosi lembar berjarak agak jauh ( sekitar 20 meter).

Pengunaan lahan pada tanah yang terkena erosi lembar adalah lahan pertanian sayuran. Tentu sayuran yang ditanam bervariasi. Pada saat pengamatan la-pangan, petani saat itu sedang menanam sawi hijau. Sedangkan penggunaan la-hanpada lahan yang terkena erosi alur adalah tanaman sawi. Tentu perbedaan pengolahan lahan yang menyebabkan bentuk erosinya berbeda dengan lahan pada erosi lembar.

Untuk erosi parit (gully erosion) tam-pak dengan rona coklat gelap/hitam pada citra III. Rona coklat hitam diakibatkan oleh bayangan dinding parit sehingga menghasilkan bayangan hitam, pantulkan energy/sinar matahari sangat rendah pada dinding ini. Erosi parit ini terjadi pada si-tus di lahan hutan pinus. Lahan secara ke-seluruhan digunakan dimiliki oleh Perhu-tani. Penduduk penggarap menyewa la-han itu..

Pola yang terlihat pada citra 2 mengelompok, artinya pola yang muncul dari tanah yang telah terkena erosi alur hanya dijumpai pada lahan hutan pinus. 


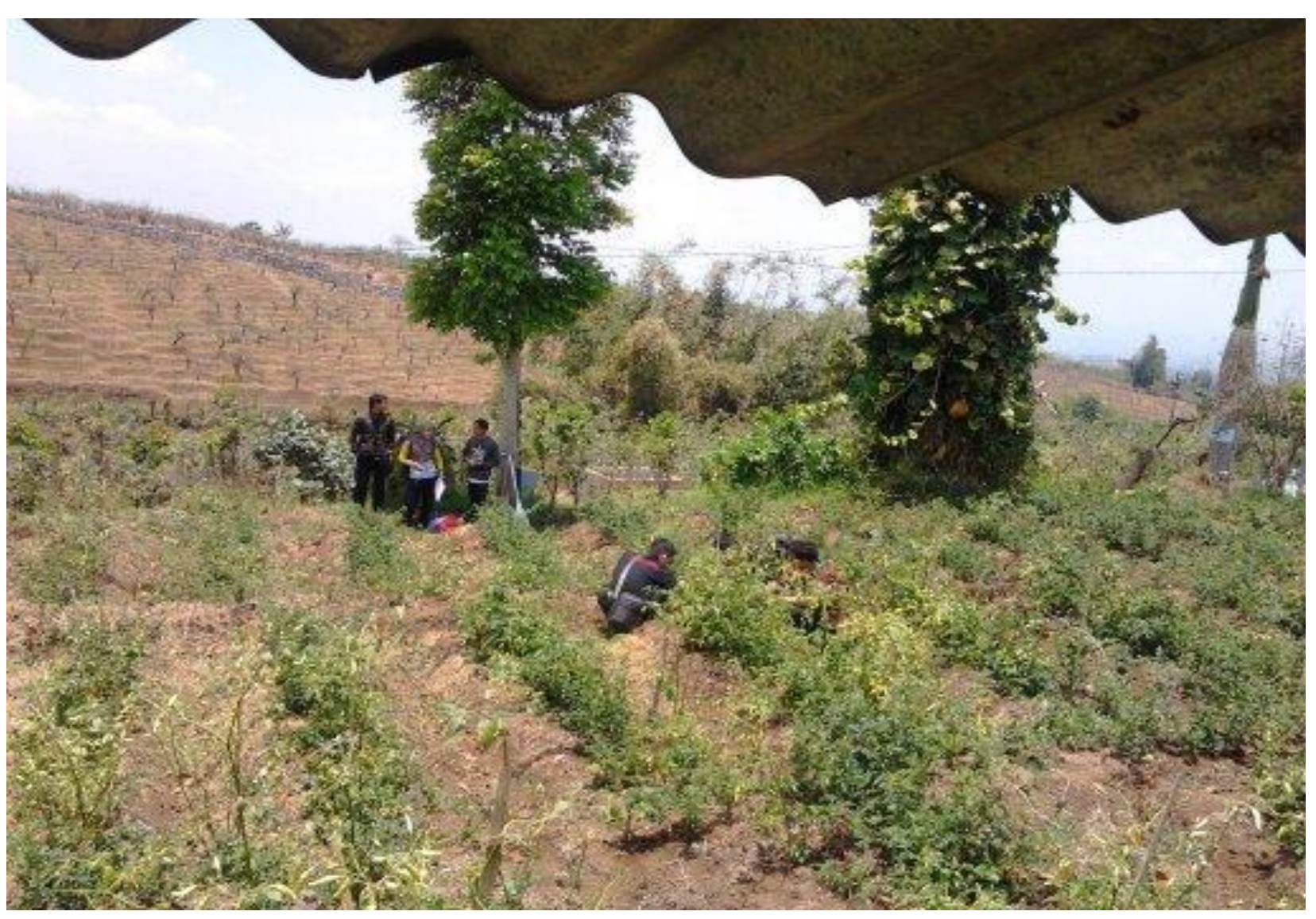

Gambar 6. Kenampakan erosi alur 
Rudi Hartono. Identifikasi Bentuk Erosi Tanah Melalui Interpretasi Citra Google

Earth Di Wilayah Sumber Brantas Kota Batu

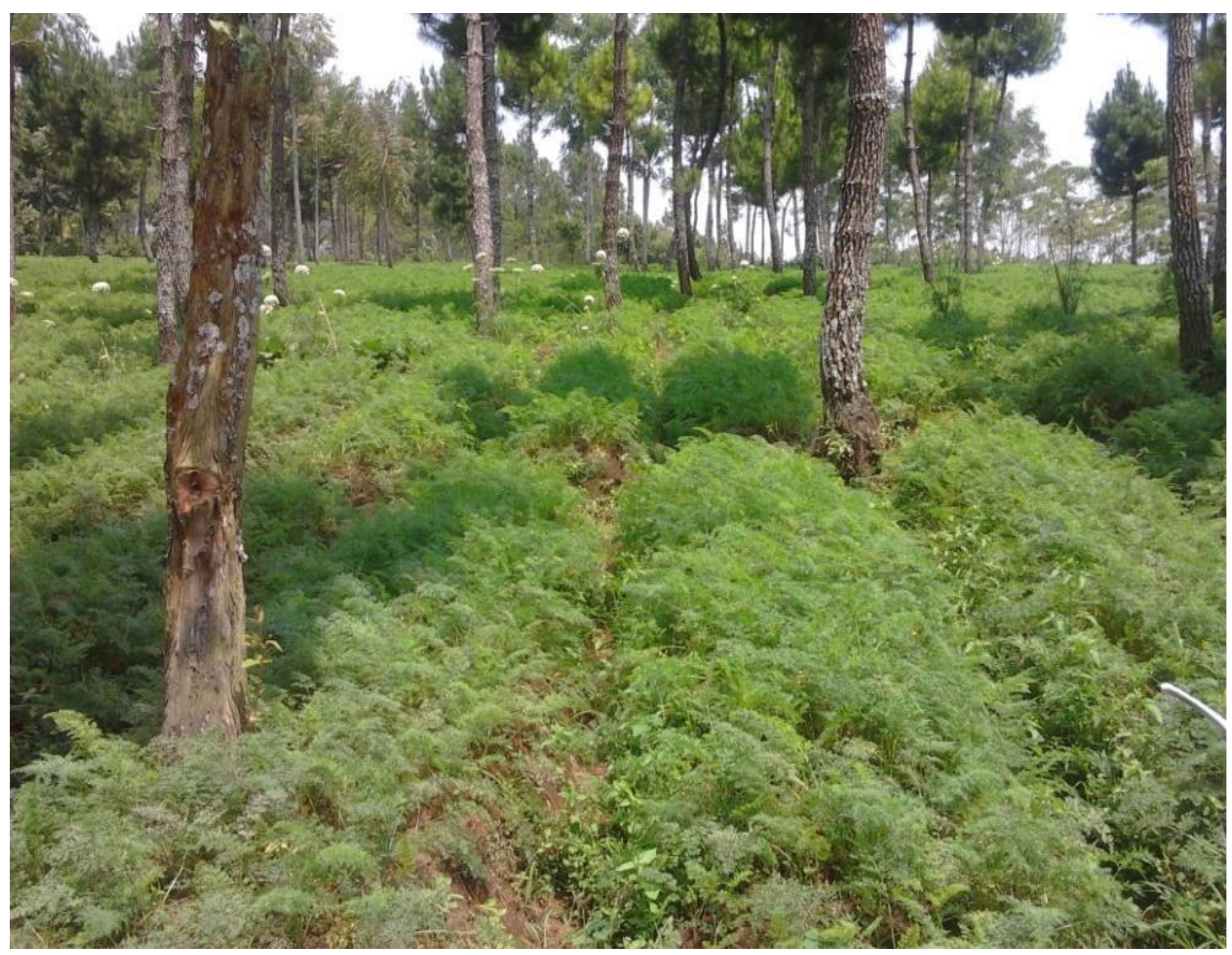

Gambar 7. Kenampakan erosi alur pada lahan hutan 


\section{KESIMPULAN}

Berdasarkan penelitian yang telah dilakukan dapat disimpulkan: 1) Identifikasi bentuk erosi tanah dapat dilakukan melalui interpretasi citra google earth dengan scala yang dibesarkan, 2) Bentuk erosi yang adapat diidentifikasi yaitu: erosi lembar, erosi alur, dan erosi parit. 3) Keterbatasan saluran citra mengurangi analisis unsur rona objek pada citra.

\section{DAFTAR PUSTAKA}

Arsyad, Sitanala. 1989. Konservasi Tanah dan Air. Institut Pertanian Bogor. Bogor.

Badan Geologi. 2010. Laporan Singkat Bencana Gerakan Tanah di Kecamatan Pagerwojo Kabupaten Tulungagung Provinsi Jawa Timur, (http://pvmbg.bgl.esdm.go.id diakses 13-02-2011 14:59)

Badan Lingkugan Hidup, (http://Lingkunganhiduptulungagung.co,cc, diakses 13-02$201123: 56)$.

Cahyo A, Hanggoro Tri. 2006. Studi Kelongsoran Pada Lereng Terbebani Silo Dengan SSR-FEM Pada Lokasi Mas Agro ResourceSungai Buaya Mill Lampung. Dinamika Teknik Sipil, Vol. 6, No. 2.

Dwikornita Karnawati, dkk. 2008. Mitigasi Bencana Berbasis Masyarakat pada Daerah Rawan
Longsor di Desa Kalitlaga Kecamatan Pagetan Kabupaten Banjarnegara Jawa Tengah. Forum Teknik Sipil, Vol. 3, No XVIII.

Hardiyatmo, Hary Christady. 2006. Penanganan Tanah Longsor dan Erosi. Yogyakarta: Gajah Mada University Press.

Hardjono, Imam. 2008. Pemintakatan Bahaya Longsor Lahan di Kecama-tan Manyaran Kabupaten Wonogiri Propinsi Jawa Tengah. Forum Geografi, Vol. 22, No. 2.

Hardjowigeno, Sarwono. 1993. Klasifikasi Tanah dan Pedogenesis. Jakarta: Akademika Pressindo.

Hari Utomo, Dwiyono. 2004. Meteorologi- Klimatologi. Malang: Universitas Negeri Malang.

Hartadi, Arief. 2009. Kajian Kesesuaian Lahan Perumahan Berdasarkan Karakteristik Fisik Dasar di Kota Fakfak. Ringkasan Tesis. Semarang: Program Pascasarjana Magister Teknik Pembangunan Wilayah dan Kota Universitas Diponegoro.

Herlambang, Sudarno. 2011. Garis Besar Geomorfologi Daerah Lintang Rendah. Malang: Universitas Negeri Malang.

Nasiah. 2000. Evaluasi Kemampuan Lahan dan Tingkat Bahaya Erosi Untuk Prioritas Konservasi Lahan di Daerah Aliran Sungai Takapala Kabupaten Dati II Gowa Propinsi Sulawesi Selatan. Tesis. Program Pasca sarjana, UGM. Yogyakarta. 